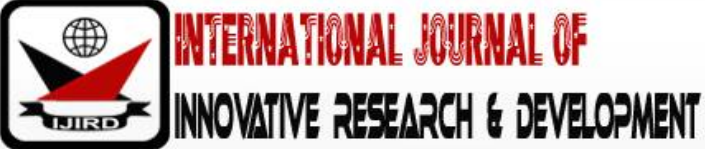

ISSN 2278 - 0211 (Online)

\section{Influence of Adoption of Modern Family Planning by Rural Women on Arable Crop Production in Southeast Nigeria}

\begin{tabular}{c}
\hline Dr. Nwaiwu Juan. C \\
Lecturer, Department of Agricultural Economics, Extension and Rural Development, \\
Imo State University, Owerri, Nigeria \\
Dr. Onubuogu Gilbert . C. \\
Lecturer, Department of Agricultural Economics, Extension and Rural Development \\
Imo State University, Owerri , Nigeria \\
Dr. Esiegeu Arthur .C. \\
Lecturer, Department of Animal Science and Fisheries, \\
Imo State University Owerri, Nigeria
\end{tabular}

\section{Abstract:}

The study assessed the influence of adoption of family planning by rural women on Arable crop production in Southeast Nigeria. The average rural women in Southeast Nigeria delivers between six to nine children but with the emphasis of the Federal Ministry of Health on adoption of family planning, the number has drastically reduced, hence the need to investigate the influence on Arable crop production. Specifically the study examined the Socioeconomic factors that influence the adoption/use of family planning, identified the methods of family planning available in the area, identified the adopters and non-adopters of family planning methods, examined the relative number and percentages of users of various family planning methods, identified the arable crops cultivated by rural women in the area, determined the farm output of adopters and the non-adopters and determined the income derived from arable crop production by adopters and non-adopters. The study hypothesized that there is no significant difference in arable crop production by adopters and non-adopters of the family planning methods. Sample size comprised one hundred and eighty (180) arable crop farmers selected using a multistage sampling method. Structural questionnaire was the main tool for data collection. Data collected were analysed using descriptive and inferential statistical tools, multiple regression was used to estimate the influence of women socio-economic characteristics on adoption of family planning. The result shows the coefficient of multiple determination (R2) to be $89.80 \%$ and was statistically significant at 1\% level of probability. $98.89 \%$ of the women identified pepper/salt solution as the most available traditional method of family planning and condom (99.44\%) as the most available modern method. Most of the women (67.22\%) did not adopt, majority of the women cultivate vegetable, cassava and maize (99.44\%, 97.78\% and 96.67\%) respectively. The mean annual farm income of adopters of family planning was N110, 500.00 while that of non-adopters was N201,700.00, the t-value of 2.464 compared with the computed value of 2.253 indicates that the $t$-value is greater than the table value at $0.5 \%$, therefore the null hypothesis was rejected. The study concludes that adoption of family planning had negative effect on arable crop production, therefore, the study recommends among others that adopters of modern family planning should engage more technology in farming to enhance their output and income, instead of relying on traditional methods of using family labour which include use of child labour.

Keywords: Adoption, Family planning, rural women, Arable crop production

\section{Introduction}

Family planning is deciding the number and spacing of your children through the use of contraception, natural planning or hormonal birth control (WHO, 2016). The subject of birth control generally creates population problems. Population here simply means any number of people inhabiting a given territory of location such as a village, city or country (Hatcher, 2007). A publication by Federal Office of Statistics (FOS) (2010) stated that "Nigeria's average population, growth rate is $2.90 \%$ and its impact on economic welfare is a serious worry. The average Nigeria woman has six children compared with five children in Ghana and Kenya (Ubong, 2008). Knowledge of modern contraception is one of the lowest in Africa, with only 7\% usage" (FOS, 2008).

Many population literatures have in various ways raised varied degrees of alarm on the population trends of the world and especially those of the third world and their attendant problems. A rural economic survey of the glorious era of agricultural production revealed that $75 \%$ of cultivable land in the western region had farms which were one hectare or less (FOS, 1968). Given the expansion in non-agricultural activities and the drastic decline in agricultural production over the decades, the situation might certainly become more deplorable. 
Ijere (1992) confirmed this by stating that the picture has not improved since then, rather it has deteriorated due to population increase and urban growth. Not only has this state of affairs affected the traditional shifting cultivation adversely; it has also brought about excessive farming on the limited available portions of land, with the attendant diminutive yields. No wonder Ekong (2010) noted the correlation between over population and poverty when the opined; "A family with ten children will most probably be poorer than one with two, other things being equal.

Women farmers are actively involved in arable crop production (Nwaiwu, 2015). The dominant activities of the women are cultivation and processing. Women are also known to be fully involved in all operations of farming including planting, thinning, weeding, fertilizer application, harvesting, storing, marketing and processing (Mgbada, 2000). Women produce between 60 and 80 percent of the food in most developing countries and are responsible for half of the world food production (FAO, 2014).

As noted in a federal office of Statistics documents "poverty is highest in rural area (FOS, 2008). The number of rural poor is roughly twice that of the urban poor. Today, even the portion of land the rural dwellers used to cultivate especially in southeast area of Nigeria have diminished significantly in size as such portion of land are shared by increasing members of the family that own them.

This study provided explanation and data on the adoption of family planning methods by rural women and its effect on arable crop production in Southeast Nigeria. Such explanations and data will provide scientific basis for the formulation of new population policies putting agriculture in mind or for the adjustment of existing ones. It contributed immensely towards improving the rate of awareness and adoption of family planning with a resultant check on rapid population growth.

\subsection{Hypothesis of the Study}

The study hypothesized that there is no significant difference in arable crop production by adopters and nonadopters of family planning methods.

\section{Methodology}

The study was carried-out in South-East agricultural zone of Nigeria. The zone is made up of five states, namely, Abia, Anambra, Ebonyi, Enugu and Imo. It has an estimated land mass of $32,610 \mathrm{~km} 2$ and a population of 22,583,076 (National Population Commission (NPC), 2006). The area lies between longitude 20611 and 60.321 east and latitudes 60741 and 80151 North of Equator with the mean annual temperature ranges from 21.6oC to $32.40 \mathrm{C}$ while the annual rainfall ranges from $720 \mathrm{~mm}$ to $1440 \mathrm{~mm}$ in the rainforest region (NIMET, 2015).

South-East Nigeria has fertile and well-drained soil and a good proportion of the population are essentially farmers. The population of this study includes all ADP rural women contact farmers in the Southeast region. Multistage sampling method was used to select respondents. First 5 States of Southeast were purposively selected. A random sampling of three states was made and in each, two agricultural zones were randomly selected. From each agricultural zone, three L.G. As were randomly selected and from each L.G.A, 10 arable crop farmers were randomly selected. These gave a sample size of 180 arable crop farmer studied.

Data was collected through primary source. The primary data was obtained using validated questionnaires that was administered through face to face interview schedules.

The study employed both quantitative and qualitative techniques in analyzing the data collected. These involved descriptive statistics such as frequency distribution, percentages and means. A regression model was used to determine the relevant socio-economic factors that influence adoption of modern family planning. Tables and figures were also employed to provide concise and vivid pictures of results and analysis. The hypothesis was analyzed using t-test.

\section{Results and Discussion}

\subsection{Estimated Influence of Women Socio-Economic Characteristic on Adoption of Family Planning}

The result of the women distribution based on estimation of influence of socio-economic characteristic on adoption of family planning in the study area is presented in Table 1. A multiple regression analysis was estimated in four functional forms (linear, semi log, double log, and exponential forms). Based on the statistical significance of the coefficients, goodness of fit and the adoption theory that supports socio-economic model. The double-log regression function was chosen as the lead equation based on the value of R2 (0.898), F-Ratio value (13.850), conformity of the signs with a priori expectations of the model and has the highest number of significant explanatory variables. The coefficient of multiple determinations (R2) was found to be $89.80 \%$ and was statistically significant at $1 \%$ level of probability. This implies that the women's socio-economic characteristic had a significant influence on their adoption of family planning in the area and that the regression model has a very high and strong explanatory power. This is an indication that $89.80 \%$ of the variation in the adoption of family planning was absolutely explained by the explanatory variables while the remaining $10.20 \%$ was explained by the stochastic variables. The marginal effect is presented as follows:

- Age (X1): The coefficient of age was positive but still significant at 5\% level of probability in a society where contraception is hardly ever used and women are strictly kept apart from any sexual relationship outside marriage, a rise in the marriage age is automatically a factor for lower fertility" (World Health Organization (WHO), 2019).

- $\quad$ Religion Belief (X2): The coefficient of religion belief was positive and significant at 1\% level of probability. That the majority of the respondents are Christians is expected to influence the adoption of family planning following the study of Nwabuisi and Mturi (2012) and Sunday et al., (2018). 
- $\quad$ Farm Size (X3): The coefficient of farm size was positive and significant at 1\% level of probability. This is true as women who owe large farmland would want to increase the number of children they have so as to help in farm work.

- Farming Experience (X4): The coefficient of farming experience was positive and significant at $1 \%$ level of probability. Going forward, the study of Esiobu (2019) opined that the number of years of farming experience helps farmers to set realistic goals.

- Awareness of Family Planning (X5): The coefficient of awareness of family planning was positive and significant at $1 \%$ level of probability. The knowledge of family planning enables women to control their family size. It guarantees citizens' health and rights; improves family's quality of life and by implication the larger society (Chukwuji et al., 2018).

- Income (X6): The coefficient of income was positive and significant at $1 \%$ level of probability. The finding is supported by the study of Osaro et al., (2017) who reported a higher acceptance of family planning method among higher income groups.

- Access to Credit (X7): The coefficient of access to credit was positive and significant at $1 \%$ level of probability. The findings are in line with the study of Wang and Mallick (2019) who reported that access to credit afford women opportunity of getting fund in adoption to family planning methods.

- Level of Education (X8): The coefficient of level of education was positive and significant at 1\% level of probability. Educated women could avoid the negative effects of family planning methods by getting appropriate advice from a service provider thereby increases their consistent use.

- Contact with Health Officers (X9): The coefficient of contact with health officers was positive and significant at $1 \%$ level of probability. The study of Imieneh et al., (2019) reported that creating connections between vulnerable populations and health care systems and facilitating health-care and social service system navigation in rural area is some of the major role of extension health officers. Therefore, service delivery strategies need to be tailored to reach populations in different locations, such as urban areas, rural towns, villages and remote areas.

The F-ratio (13.850), which determines the overall significance of the regressor was highly significant at $1 \%$ level of probability. This implies that the explanatory variables jointly exerted great influence on the adoption of family planning by the women in the area. This compels the researcher to rejecting the null hypothesis of the study which states that, "there is no significant influence between women socio-economic characteristics and adoption of family planning in the area. Hence the researcher concludes that the socio-economic characteristic of women influences adoption of family planning method in the area.

\subsection{Method of Family Planning Available in the Area}

The result of the rural women distribution based on methods (traditional and modern) of family planning available in the area is presented in Table 2. From the traditional method, it reveals that majority (98.89\%) of the women identified Pepper/Salt Solution as one of the methods of family planning available in the area. This is true as this method is cheap and always available.

The effectiveness of common pepper/salt as a spermicidal contraceptive was reported by the study of (Westley et al., 2013). Supersaturated solutions of common salt applied high in the vagina causes immediate death of all sperm (Ajayi et al., 2016). Moving on, as complied in table 2, about 94.44\%, 93.33\%, 87.22\%, 85.00\% and 18.89\% of the women identified Herbs/Roots, Timing, Prolonged Breast Feeding, Abstinence/Separate Living and Polygamy respectively as one of the various methods of family planning available in the area. About $1.67 \%$ the women identified abortion as one of the various methods of family planning.

The small proportion recorded in abortion could be due to legal, religious and cultural issues associated with it. Similarly, table 2 also displayed the modern method of family planning available in the area. It shows that greater proportion (99.44\%) identified condom as one of the modern methods of family planning available in the area. In the same way, about $85.00 \%, 83.33 \%$ and $78.89 \%$ of the women identified Oral Contraceptives/Pills, Vaginal Cream and Foaming Tablets respectively. Diaphragm, Intra-Uterine Device (IUD) and Injectables were identified by about $75.56 \%, 68.89 \%$ and $66.67 \%$ of the women as one of the various methods of family planning in the area. Very little proportion (7.78\%) identified sterilization as one of the various methods of family planning in the area. This could be because sterilization is a permanent method of contraception that makes couple unable to give birth again. Therefore, the finding implies that there are various methods of family planning available in the area.

\subsection{Adopters and Non-adopters of Family Planning in the Area}

The results of the rural women distribution based on adopters and non-adopters of family planning in the area are shown in Table 3. It reveals that approximately $67.22 \%$ of the rural women have not adopted family planning while about $32.78 \%$ have adopted various family planning methods available in the area. The finding shows that smaller proportions of women are using family planning method in the area. The finding is true, as it is supported by the study of National Population Commission (NPC) and United Nations Department of Economics and Population Division (UNDESAPD) (2019) which found that contraceptive prevalence in Nigeria is one of the lowest in the world. The study further reported that although $85.00 \%$ and $95.00 \%$ of Nigerian women and men respectively have knowledge of a contraceptive method, only about $15.00 \%$ of currently married women use a contraceptive method, with an unmet need for family planning of $16.00 \%$ among married women. Rural women are known to show reluctance towards utilization of family planning (Chukwuji et al., 2018). Additionally, one of the key determinants of use of family planning methods in Nigeria is female education. 


\subsection{Relative Number and Percentage of Users of Various Family Planning Methods}

The result of the rural women distribution based on relative number and percentage of users of various family planning methods in the area is compiled in Table 4. The various family planning methods were rated in a 2-point Likert scale type of questions of user (3) and non-user (2). Using the method of mean score analysis, a discriminatory mean of 2.50 was produced which divided the distribution into two, user (3) and non-user (2). The mean value of each attribute equal to or above 2.50 was regarded as being a major user while attributes with mean value less than 2.50 was regarded as none user. By these criteria, all the attributes were perceived as being various family planning methods. The items included in the rating were various traditional and modern method of family planning in the area. For traditional method, the use of Pepper/Salt Solution $(X=2.96)$ was the frequently used traditional method of family planning in the area. This could be as a result of its availability at home. More so, all the items were rated high and had an acceptable discriminatory score ( $X=2.50)$ except Abstinence/Separate Living ( $X=2.03)$; Poligyny ( $\mathrm{x}=2.23)$ and abortion $(\mathrm{x}=2.05)$ most men in the area do not marry more wife as a means of family planning as this is not their culture. Additionally, as for polygyny, is not predominate in the area which is the south-eastern part of Nigeria. Abortion, though unplanned is an unpleasant and harrowing experience for women. Therefore, greater numbers of women do not adopt abortion as a means of family planning.

Moving on, from the modern methods of family planning, the Condom $(X=2.99)$ was the most frequently use method of family planning in the area. Condoms are one of the types of contraception that can both prevent pregnancy and protect against sexually transmitted infections (STIs) (Komasawa et al., 2020). In the same way, all the method was accepted expect Vaginal Cream (X=2.21); Diaphragm ( $X=2.24)$; Intra-Uterine Device (IUD) ( $\mathrm{X}=2.31)$; Injectables (X=2.33) and Sterilization $(X=2.33)$. This could be as a result of the various complications associated with the use of them.

\subsection{Different Arable Crops Produced by the Rural Women in the Area}

The result of the rural women distribution based different arable crops produced in the area is displayed in Table 5. It reveals that about $99.44 \%, 97.78 \%$ and $96.67 \%$ of the women were involved in vegetable, cassava and maize production respectively. The finding is in consonant with the study of Nakwe et al., (2018) who opined that rural women are the main producers of staple crops as well as the production of secondary crops such as legumes, vegetables, roots and tubers. Similarly, approximately, 95.00\%, 91.67\%, 90.00\%, 81.11\% and 76.67\% of the rural women produces yam, melon, cocoyam, rice and garden-egg respectively. In the same way, groundnut, cucumber, cowpea and potatoes were produced by about $75.56 \%, 72.22 \%, 70.56 \%$ and $51.67 \%$ of the rural women in the area. The finding implies that women in the area produce one or more crops even in the tedious midst of child bearing and nurturing.

\subsection{Average Income Derived from Arable Crops by Adopters of Family Planning Methods}

The result of average income derived from arable crops by adopters of family planning methods is presented in Table 6. The mean annual farm income of the adopters of family planning method in the area was N110,500.00. This shows a relatively low farm income of the adopters of family planning. This is expected as adopters of family planning method may have issue with farm labour to expand production thereby leading to relatively low output which will translate to low income. This situation of low income may as well pose a barrier to the women continues adoption and use of family planning methods in the area. The findings share view with the study of Yihunie et al., (2013); Eliason et al., (2014) who reported that family planning was more common among women with higher household income and highest wealth quintile.

\subsection{Average Income Derived from Arable Crops by Non-Adopters of Family Planning Methods}

The result of average income derived from arable crops by non-adopters of family planning methods is shown in Table 7. The mean annual farm income of the adopters of family planning method in the area was N201,700.00. This is high and almost the doubled of the average income realized by adopters of family planning method in the area. This relatively high farm income could be associated with the availability of farm labour for non-adopters of family planning methods. It is also known that women with higher family size will require more income than women with lower family size. The study of Babalola et al., (2012) argued that increase in these income variables would increase the probability of women use of family planning methods. However, these could be said not to be entirely true for non-adopters as a lot of factors such as awareness, education and access could be other determinant.

\subsection{Comparisons of Adopted and Non-Adopted Output of Arable Crop Women in Family Planning Method}

In order to compare the adopted and non-adopted output of arable crop women in family planning method in the area, the t-statistics was used as shown in Table 8.The mean, standard deviation, standard error of means and the t-value of the two variables (Adopted and Non-Adopted Output) were obtained. The mean (X) output of the adopted and nonadopted output was $1,650 \mathrm{~kg}$ and $3,760 \mathrm{~kg}$ respectively. The standard deviation $(\sigma)$ of the adopted and non-adopted output rates were $1.2920 \mathrm{~kg}$ and $0.02890 \mathrm{~kg}$ respectively.

With the result it could be asserted that there is a significant difference $(p>0.05)$ between the output of those who adopted family planning method and those who do not. This implies that those who adopted and practice family planning method had less farm output than those who adopted. This could be as a result of family labour available for non-adopters of family planning. Non-adopters of family planning tend to give birth without control thereby having high number of children who will serve as a source of labour in the farm activities. It is also clear that they may tends to consume more food from the same farm than there who give birth to number of children that can adequately cater-for. 
Additionally, women who adopt family planning methods tend to give birth to number of children they can adequately carter-for. Due to few numbers of children, they do not get the much-needed farm labour from household to expand their production and increase their yield per farming season. In the same way, using the degree of freedom value as 358.00 and at $0.5 \%$ level of significance, a look at the t-value distribution table gives a value of 2.464 . Comparing this value against the computed value of 2.253 indicates that the calculated t-value is greater than the table value at a significance level of $0.5 \%$. Therefore, it is safe to reject the null hypothesis that there is a difference between means. Ultimately, it could be concluded that there is a significant difference $(\mathrm{p}<0.05)$ between the output of those who adopted family planning methods and those who do not in the study area.

\section{Conclusion}

The women were arable crop farmers who mostly engaged family labour in production including child labour. Non-adopters of family planning methods had large output and income than the adopters because they had more supply of family labour which included child labour for their production. Therefore, adoption of modern family planning methods had negative effect on arable crop production and its adoption means less children and less availability of child labour for farm work. This is because the use of child labour in farm work is practiced in the area. Therefore the study recommends that there should be more effort to create awareness of use of modern family planning method in the study area, and more health workers should be deployed to the rural areas to educate the women on the need to embrace modern family planning methods, Adopters of modern family planning should engage more technology in farming to enhance their output and income, instead of relying on traditional methods of using family labour which include use of child labour.

\section{References}

i. Ajayi, A. I, Ezebunwa E.N, Akpan, W and Oladele V.A (2016). Use of non-emergency contraceptive pills and concoctions as emergency contraception among Nigerian University students: results of a qualitative study; BMC Public Health volume 16, Article number: 1046

ii. Babalola, D.A, Babalola Y.T and Oladimeji, A.A (2012). Assessing the use of Family Planning Information among Farming Households in Nigeria: Evidence from Ogun State. Asian Journal of Rural Development, 2: 40-46.

iii. Chukwuji, C.N; Tsafe, A.G, Sayudi, S, Yusuf, Z and Zakarriya, J, (2018). Awareness, Access and Utilization of Family Planning Information in Zamfara State, Nigeria; Library Philosophy and Practice (e journal).1771. https://digitalcommons.unl.edu/libphilprac/1771

iv. Ekong, E.E. (2010): An Introduction to Rural Sociology (3rd edition); Dove Educational Publishers, Uyo, Nigeria. Pp. 241-295.

v. Eliason, S., Awoonor-Williams, J.K., Eliason, C. (2014). Determinants of modern family planning use among women of reproductive age in the Nkwanta district of Ghana: a case-control study. Reprod Health 11, 65; https://doi.org/10.1186/1742-4755-11-65

vi. Esiobu, N. S (2019). Understanding the Allocative Efficiency of Cassava Farms in Imo State, Nigeria; Journal of Economics and Sustainable Development; 10(19):82-93

vii. Federal Office of Statistics (FOS), (1968): Rural Demographic sample survey 1963-65. FOS, Lagos.

viii. Federal Office of Statistics (FOS), (2010): 2007/2008 General Household Survey National Report, FOS, Abuja.

ix. Federal Office of Statistics (FOS)Z (2008): Poverty and Agricultural sector in Nigeria. FOS, Abuja

x. Food and Agricultural Organization (FAD) (2014): Report of the Second Consultation on Agricultural Information Management. Rome, Italy.

xi. Hatcher, R.A (2007). Contraceptive Technology. 19th Revised Edition. Ardent Media, Inc., New York, 2007

xii. Ijerez M. (1992): Leading Issues on Rural Development. ACENA Publishers, Enugu. P. 20.

xiii. Imieneh, M.M, Mengistu M.Y, Gelagay A.A (2019). Mothers' health care seeking behavior and associated factors for common childhood illnesses, Northwest Ethiopia: community based cross-sectional study. BMC Health Serv Res. 2019; 19:59

xiv. Komasawa, M, Yuasa M, Shirayama Y, Sato M, Komasawa Y, Alouri M (2020). Demand for family planning satisfied with modern methods and its associated factors among married women of reproductive age in rural Jordan: A cross-sectional study. PLoS ONE 15(3): e0230421. https://doi.org/10.1371/journal.pone.0230421

xv. Mgbada, J.U. (2010): Agricultural Extension: The Human Development Perspective Computer Edge Publishers, Enugu. Pp.436.

xvi. Nakwe, G, Mahmood, H, Ndaghu, A, Bashir, B and Kyaru M (2018). Assessment of Women Participation in Vegetable Production Activities in ADP, Zone III, Taraba State, Nigeria; Asian Journal of Agricultural Extension, Economics \& Sociology 27(2): 1-16,

xvii. National Population Commission (NPC), (2006): Provisional Census Figures. Abuja, Nigeria Iloka A.W. and F.O. Anuebunwa, (2005). Appraisal study of the Agricultural Extension System of Nigeria; South-East Agro Ecological Zone of Nigeria Unpublished Manuscript.

xviii. Nwabuisi, 0 and Mturi, A.J (2012). Do religious beliefs influence use of contraception among currently married women in Nigeria? Journal of social development in Africa 28(1):187-212

xix. Nwaiwu, J.C. (2015): Socio-Economic Factors Influencing Arable Crop Farmers Adoption of Environmental Conservation Measures in South Eastern Nigeria. International Journal of Research in Agriculture and forestry, 23(3):20-25.

xx. Osaro, B.0, Tobin-West C.I, Mezie-Okoye M.M (2017). Knowledge of modern contraceptives and their use among rural women of childbearing age in Rivers State Nigeria. Ann Trop Med Public Health 2017; 10:1043-8 
xxi. Sunday, A. A, Babalola, S, Ibeawuchi, A, Olukunle, O, Akinsewa A, and Mojisola O (2018). Role of Religious Leaders in Promoting Contraceptive Use in Nigeria: Evidence From the Nigerian Urban Reproductive Health Initiative; Glob Health Sci Pract. 2018 Oct 3; 6(3): 500-514.

xxii. Ubong A.A. (2008): Livelihood Activities and Poverty Alleviation among Rural women in Akwa Ibom State, Nigeria. Unpublished Ph. D Thesis, Department of Rural Sociology, Micheal Okpara University of Agriculture Umudike.

xxiii. United Nations, Department of Economic and Social Affairs, Population Division (UNDESAPD) (2019). Contraceptive Use by Method 2019: Data Bookle (ST/ESA/SER.A/435).

xxiv. Wang, W and Mallick L (2019). Understanding the relationship between family planning method choices and modern contraceptive use: an analysis of geographically linked population and health facilities data in Haiti BMJ Global Health;4: e000765.

xxv. Westley, E, Kapp N, Palermo T, Bleck J. (2013). A review of global access to emergency contraception. Int J Gynecol Obstet. 2013;123(1):4 6.

xxvi. World Health Organization (WHO), (2019). Reproductive health of Women. www.who.int/reproductivehealth/topics/family_planning/statement_collective/_ Acti on.pdf (Accessed: October 2019).

xxvii. Yihunie, Y, Reda A.A, Tamene H, Benedict S, Deribe K (2013). Geographical variation and factors influencing modern contraceptive use among married women in Ethiopia: evidence from a national population-based survey. Reprod Health J. 2013, doi:10.1186/1742-4755-10-52, http://www.reproductive-healthjournal.com/content/10/1/ 52 .

Appendix

\begin{tabular}{|c|c|c|c|c|}
\hline Explanatory Variables & Linear & Semi-Log & Double-Log & Exponential \\
\hline Constant & $\begin{array}{l}29.837 \\
(12.910)^{* * *}\end{array}$ & $\begin{array}{l}51.801 \\
(8.973)^{* * *}\end{array}$ & $\begin{array}{l}82.852 \\
(18.928)^{* * *}\end{array}$ & $\begin{array}{l}-10.630 \text { E86 } \\
(-8.610)^{* * * *}\end{array}$ \\
\hline Age $\left(\mathrm{X}_{1}\right)$ & $\begin{array}{l}0.073 \\
(1.409)^{*}\end{array}$ & $\begin{array}{l}2.688 \\
(1.075)^{*}\end{array}$ & $\begin{array}{l}0.0113 \\
(2.178)^{* *}\end{array}$ & $\begin{array}{l}-3.994 \mathrm{E}-18 \\
(-0.906)\end{array}$ \\
\hline Religion Belief $\left(\mathrm{X}_{2}\right)$ & $\begin{array}{l}0.736 \\
(0.856)\end{array}$ & $\begin{array}{l}0.760 \\
(0.835)\end{array}$ & $\begin{array}{l}0.027 \\
(2.778)^{* * *}\end{array}$ & $\begin{array}{l}-5.462 \mathrm{E} 7 \\
(-0.317)\end{array}$ \\
\hline Fam Size $\left(\mathrm{X}_{3}\right)$ & $\begin{array}{l}6.846 \\
(3.609)^{* * *}\end{array}$ & $\begin{array}{l}1.82 \\
(3.795)^{* * *}\end{array}$ & $\begin{array}{l}0.068 \\
(3.684)^{* * *}\end{array}$ & $\begin{array}{l}1.103 \mathrm{E} 13 \\
(1.922)^{*}\end{array}$ \\
\hline Faming Experience $\left(\mathrm{X}_{4}\right)$ & $\begin{array}{l}0.078 \\
(1.497)\end{array}$ & $\begin{array}{l}8.058 \\
(.0730)\end{array}$ & $\begin{array}{l}0.001 \\
(2.044)^{* *}\end{array}$ & $\begin{array}{l}-2.019 \mathrm{E}-8 \\
(-0.359)\end{array}$ \\
\hline $\begin{array}{l}\text { Awareness of Family Planning } \\
\left(\mathrm{X}_{5}\right)\end{array}$ & $\begin{array}{l}0.299 \\
(1.648)^{*}\end{array}$ & $\begin{array}{l}2.325 \\
(1.744)^{*}\end{array}$ & $\begin{array}{l}0.094 \\
(2.846)^{* * *}\end{array}$ & $\begin{array}{l}-1.822 \mathrm{E} 7 \\
(0.210)\end{array}$ \\
\hline Income $\left(\mathrm{X}_{6}\right)$ & $\begin{array}{l}-0.040 \\
(-2.586)^{* * *}\end{array}$ & $\begin{array}{l}1.637 \\
(2.180)^{* *}\end{array}$ & $\begin{array}{l}0.059 \\
(2.050)^{* *}\end{array}$ & $\begin{array}{l}-4.114 \mathrm{E}-57 \\
(-0.210)\end{array}$ \\
\hline Access to Credit $\left(\mathrm{X}_{7}\right)$ & $\begin{array}{l}0.186 \\
(0.239)\end{array}$ & $\begin{array}{l}1.011 \\
(1.353)^{*}\end{array}$ & $\begin{array}{l}0.038 \\
(2.339)^{* *}\end{array}$ & $\begin{array}{l}-1.433 E 12 \\
(-0.666)\end{array}$ \\
\hline Level of Education $\left(\mathrm{X}_{8}\right)$ & $\begin{array}{l}0.134 \\
(1.942)\end{array}$ & $\begin{array}{l}0.639 \\
(1.029)\end{array}$ & $\begin{array}{l}0.028 \\
(2.545)^{* * *}\end{array}$ & $\begin{array}{l}-13644.805 \\
(-1.089)^{*}\end{array}$ \\
\hline $\begin{array}{l}\text { Contact with Health Officers } \\
(\mathrm{X} 9)\end{array}$ & $\begin{array}{l}0.756 \\
(2.012)^{* *}\end{array}$ & $\begin{array}{l}0.923 \\
(2.500)^{* * *}\end{array}$ & $\begin{array}{l}0.036 \\
(2.556)^{* *}\end{array}$ & $\begin{array}{l}2.257 \mathrm{E} 11 \\
(0.631)\end{array}$ \\
\hline $\mathrm{R}^{2}$ & 64.70 & 69.50 & 89.80 & 57.40 \\
\hline $\mathrm{R}^{2}$ & 61.60 & 63.90 & 86.20 & 53.10 \\
\hline F-Ratio & $8.751^{* * *}$ & $10.850 * * *$ & $13.850 * * *$ & $5.820 * * *$ \\
\hline
\end{tabular}

Table 1: Estimated Influence of Women Socio-economic Characteristic on Adoption of Family Planning Source: Computer Printout of SPSS (2020); Values in Parenthesis are t-values *Statistically Significant at 10\%;

**Statistically Significant at 5\%; *** Statistically Significant at 1\%

\begin{tabular}{|llll|}
\hline S/No & Method of Family Planning & Frequency & Percentage (\%) \\
\hline & Traditional Method & & \\
$\mathbf{1}$ & Pepper/Salt Solution & 178 & 98.89 \\
$\mathbf{2}$ & Withdrawal & 175 & 97.22 \\
$\mathbf{3}$ & Herbs/Roots & 170 & 94.44 \\
$\mathbf{4}$ & Timing & 168 & 93.33 \\
$\mathbf{5}$ & Prolonged Breast Feeding & 157 & 87.22 \\
$\mathbf{6}$ & Abstinence/Separate Living & 153 & 85.00 \\
$\mathbf{7}$ & Polygamy & 34 & 18.89 \\
$\mathbf{8}$ & Abortion & 2 & 1.67 \\
& Modern Method & Frequency & Percentage (\%) \\
$\mathbf{1}$ & Condom & 179 & 99.44 \\
$\mathbf{2}$ & Oral Contraceptives/Pills & 153 & 85.00 \\
$\mathbf{3}$ & Vaginal Cream & 150 & 83.33 \\
$\mathbf{4}$ & Foaming Tablets & 142 & 78.89 \\
$\mathbf{5}$ & Diaphragm & 136 & 75.56 \\
$\mathbf{6}$ & Intra-Uterine Device (IUD) & 124 & 68.89 \\
$\mathbf{7}$ & Injectables & 120 & 66.67 \\
$\mathbf{8}$ & Sterilization & 92 & 51.11 \\
\hline
\end{tabular}

Table 2: Method of Family Planning Available in the Area

*Multiple Responses Were Recorded

Source: Field Survey Data, 2020 


\begin{tabular}{|lll|}
\hline Variables & Frequency & \\
\hline Adopters & 59 & Percentage (\%) \\
Non-adopters & 121 & 32.78 \\
\hline Total & $\mathbf{1 8 0}$ & 67.22 \\
\hline & & $\mathbf{1 0 0 . 0}$ \\
\hline
\end{tabular}

Table 3: Adopters and Non-Adopters of Family Planning in the Area Source: Field Survey Data, 2020

\begin{tabular}{|c|c|c|c|c|c|c|}
\hline S/No & Family PlanningMechods & $\begin{array}{l}\text { Users } \\
\text { (3) }\end{array}$ & $\begin{array}{l}\text { Non Users } \\
\text { (2) }\end{array}$ & $\begin{array}{l}\text { Mean } \\
(2.50)\end{array}$ & Renark & Total (n) \\
\hline 1 & $\begin{array}{l}\text { Traditional Method } \\
\text { Pewer Salt Solution }\end{array}$ & $\begin{array}{l}173 \\
(96.11 \%)\end{array}$ & $\begin{array}{l}7 \\
(3.89 \%)\end{array}$ & 2.96 & Accepted & 180 \\
\hline 2 & Withdraw al & $\begin{array}{l}177 \\
(98.33 \%)\end{array}$ & $\begin{array}{l}3 \\
(1.67 \%)\end{array}$ & 2.96 & Accepted & 180 \\
\hline 3 & Hets Roots & $\begin{array}{l}63 \\
(35.00 \%)\end{array}$ & $\begin{array}{l}117 \\
(65.00 \%)\end{array}$ & 2.98 & Accepted & 180 \\
\hline 4 & Timng & $\begin{array}{l}162 \\
(90.00 \%)\end{array}$ & $\begin{array}{l}18 \\
(10.00 \%)\end{array}$ & 2.35 & Rejated & 180 \\
\hline 5 & Polonged Breast Feeding & $\begin{array}{l}54 \\
(30.00 \%)\end{array}$ & $\begin{array}{l}126 \\
(70.00)\end{array}$ & 2.90 & Accepted & 180 \\
\hline 6 & Abstinence/Separate Living & $\begin{array}{l}6 \\
(3.33 \%)\end{array}$ & $\begin{array}{l}174 \\
(96.67 \%)\end{array}$ & 2.03 & Rejeted & 180 \\
\hline 7 & Polygyny & $\begin{array}{l}39 \\
(21.67 \%)\end{array}$ & $\begin{array}{l}141 \\
(78.33 \%)\end{array}$ & 2.23 & Rejerted & 180 \\
\hline \multirow[t]{2}{*}{8} & Abortion & $\begin{array}{l}1 \\
(0.56)\end{array}$ & $\begin{array}{l}179 \\
(99.44 \%)\end{array}$ & 2.05 & Rejated & \\
\hline & Modern Method & $\begin{array}{l}\text { Users } \\
\text { (3) }\end{array}$ & $\begin{array}{l}\text { Non Users } \\
\text { (2) }\end{array}$ & $\begin{array}{l}\text { Mean } \\
(2.50)\end{array}$ & Remark & Total (n) \\
\hline 1 & Condon & $\begin{array}{l}178 \\
(98.89 \%)\end{array}$ & $\begin{array}{l}2 \\
(1.11 \%)\end{array}$ & 299 & Accepted & 180 \\
\hline 2 & Otal Contracpetves/Pills & $\begin{array}{l}172 \\
(95.56 \%)\end{array}$ & $\begin{array}{l}8 \\
(4.44 \%)\end{array}$ & 2.96 & Accepted & 180 \\
\hline 3 & Vaginal Cream & $\begin{array}{l}37 \\
(20.56 \%)\end{array}$ & $\begin{array}{l}143 \\
(79.44 \%)\end{array}$ & 2.21 & Rejeted & 180 \\
\hline 4 & Foaming Tablets & $\begin{array}{l}129 \\
(71.67 \%)\end{array}$ & $\begin{array}{l}51 \\
(28.33 \%)\end{array}$ & 2.72 & Accepted & 180 \\
\hline 5 & Diaghragm & $\begin{array}{l}44 \\
(24.44 \%)\end{array}$ & $\begin{array}{l}136 \\
(75.56 \%)\end{array}$ & 2.24 & Rejeted & 180 \\
\hline 6 & Itta-Uterine Device (IUD) & $\begin{array}{l}56 \\
(31.11 \%)\end{array}$ & $\begin{array}{l}124 \\
(68.89 \%)\end{array}$ & 2.31 & Rejeted & 180 \\
\hline 7 & hjectables & $\begin{array}{l}60 \\
(33.33 \%)\end{array}$ & $\begin{array}{l}120 \\
(66.67 \%)\end{array}$ & 2.33 & Rejeted & 180 \\
\hline 8 & Stenlization & $\begin{array}{l}1 \\
(0.56 \%)\end{array}$ & $\begin{array}{l}179 \\
(99.44 \%)\end{array}$ & 2.00 & Rejated & 180 \\
\hline
\end{tabular}

Table 4: Relative Number and Percentage of Users of Various Family Planning Methods Discriminatory Mean: Cut Off Point 2.50 Accepted; *Figures in Parenthesis Are Percentage, Field Survey Data,

Discriminatory Mean: Cut Off Point 2.50 Accepted; *Figures In Parenthesis Are Percentage; Field Survey Data,2020

\begin{tabular}{|llll|}
\hline S/No & Arable Crops & Frequency & Percentage (\%) \\
\hline 1 & Vegetables & 179 & 99.44 \\
2 & Cassava & 176 & 97.78 \\
3 & Maize & 174 & 96.67 \\
4 & Yam & 171 & 95.00 \\
5 & Melon & 165 & 91.67 \\
6 & Cocoyam & 162 & 90.00 \\
7 & Rice & 146 & 81.11 \\
8 & Garden Egg & 138 & 76.67 \\
9 & Groundnut & 136 & 75.56 \\
10 & Cucumber & 130 & 72.22 \\
11 & Cowpea & 127 & 70.56 \\
12 & Potatoes & 93 & 51.67 \\
\hline
\end{tabular}

Table 5: Different Arable Crops Produced by the Rural Women in the Area *Multiple Responses Were Recorded Source: Field Survey Data, 2020 


\begin{tabular}{lll|}
\hline Average Annual Farm Income ( $\mathrm{N})$ & Frequency & Percentage (\%) \\
\hline $\mathbf{1 , 0 0 0 - 3 0 , 0 0 0}$ & 2 & 3.39 \\
$\mathbf{3 0 , 0 0 1 - 6 0 , 0 0 0}$ & 4 & 6.78 \\
$\mathbf{6 0 , 0 0 1 - 9 0 , 0 0 0}$ & 5 & 8.47 \\
$\mathbf{9 0 , 0 0 1 - 1 2 0 , 0 0 0}$ & 33 & 55.93 \\
$\mathbf{1 2 0 , 0 0 1 - 1 5 0 , 0 0 0}$ & 10 & 16.95 \\
$\mathbf{1 5 0 , 0 0 1 - 1 8 0 , 0 0 0}$ & 4 & 6.78 \\
$\mathbf{1 8 0 , 0 0 1 - 2 1 0 , 0 0 0}$ & 1 & 1.70 \\
\hline Total & $\mathbf{5 9}$ & $\mathbf{1 0 0 . 0}$ \\
\hline
\end{tabular}

Table 6: Average Income Derived from Arable Crops by Adopters of Family Planning Methods Source: Field Survey Data, 2020

\begin{tabular}{|lll|}
\hline & & \\
\hline Average Annual Farm Income (N) & Frequency & Percentage (\%) \\
\hline $\mathbf{1 , 0 0 0 - 3 0 , 0 0 0}$ & 2 & 1.65 \\
$\mathbf{3 0 , 0 0 1 - 6 0 , 0 0 0}$ & 5 & 4.13 \\
$\mathbf{6 0 , 0 0 1 - 9 0 , 0 0 0}$ & 6 & 4.96 \\
$\mathbf{9 0 , 0 0 1 - 1 2 0 , 0 0 0}$ & 9 & 7.44 \\
$\mathbf{1 2 0 , 0 0 1 - 1 5 0 , 0 0 0}$ & 7 & 5.76 \\
$\mathbf{1 5 0 , 0 0 1 - 1 8 0 , 0 0 0}$ & 17 & 14.05 \\
$\mathbf{1 8 0 , 0 0 1 - 2 1 0 , 0 0 0}$ & 75 & 61.98 \\
\hline Total & $\mathbf{1 2 1}$ & $\mathbf{1 0 0 . 0}$ \\
\hline
\end{tabular}

Table 7: Average Income Derived from Non-Arable Crops by Adopters of Family Planning Methods

Source: Field Survey Data, 2020

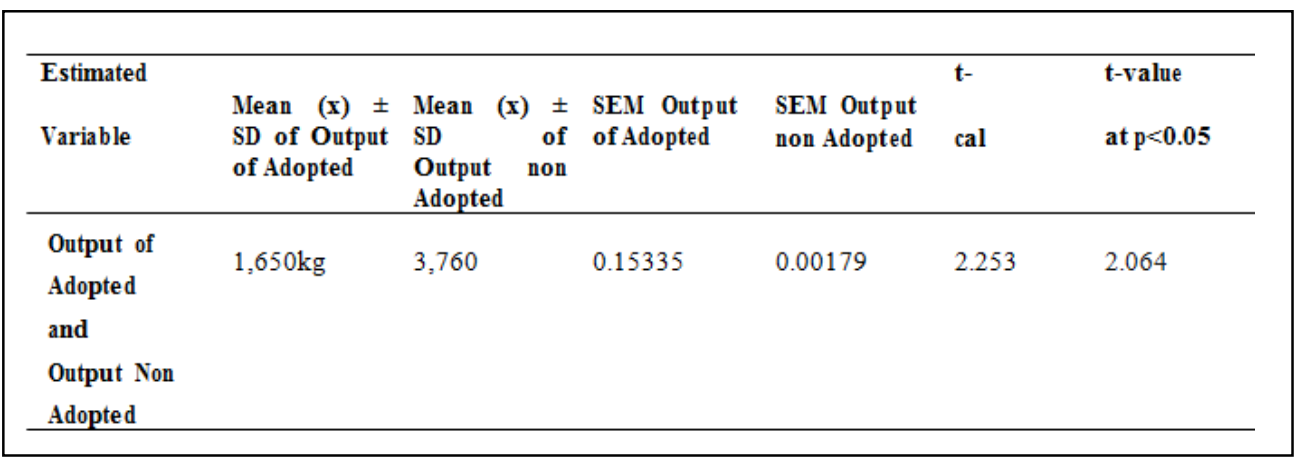

Table 8: Distribution of Comparisons of Adopted and Non-Adopted Output of Arable Crop Women in Family Planning Method

Source: Computer Printout of SPSS (2020); SD; Standard Deviation; SEM; Standard Error of Means, T-Values Are Statistically Significantly $(P<0.05)$ 